\title{
Tannery Waste Water Treatment through Aggregation of Bio-sorption and Chemical Coagulation Aided by Indigenous Coagulant
}

\author{
Subrata Paul*, Thuhin Kumar Dey and Rajan Kumar Raha \\ Department of Leather Engineering, Khulna University of Engineering \& Technology, Khulna, Bangladesh
}

Received 12 May 2018, Accepted 14 July 2018, Available online 17 July 2018, Vol.8, No.4 (July/Aug 2018)

\begin{abstract}
Tannery in Bangladesh seems a source of pollution load and waste water to all because there are 270 registered tanneries where approximately 220 MT raw hides and skins are taking for the production of leather in Bangladesh. The leather industry has crossed the record \$1-billion mark in exports in 2013-2014. According to the Department of Environment, the tanneries discharge 22,000 cubic meters of untreated liquid toxic waste daily. These pollution load and waste water should need treatment to make environmentally sustainable and living. From this point of view, we worked on tannery waste water processing. The paper highlights the initiation of Algal treatment with chemical coagulation process aided by natural coagulant for waste water processing in Bangladesh. The methodology of this process starts with mixing of waste water from different section of beam house operations at a definite ratio. The mixer takes nearly six hours to settle down. After sedimentation, the turbidity decreases at a reasonable amount i.e. 1428 NTU whereas before sedimentation it was 9050 NTU (2100P Turbid Meter of HACH). Later the supernatant was collected for algal treatment. After algal treatment the turbidity reduced to $530 \mathrm{NTU}$ from $1428 \mathrm{NTU}$ and the DO level increased up to $4.48 \mathrm{mg} / \mathrm{L}$ at $33.6^{\circ} \mathrm{C}(\mathrm{HQ} 40 \mathrm{~d}$ of $\mathrm{HACH})$ where DO level was $0.24 \mathrm{mg} / \mathrm{L}$ at $33.6^{\circ} \mathrm{C}$ in raw mixer. In addition, the amount of alum as chemical coagulant was reduced in tannery waste water treatment by using indigenous snail shell powder as coagulant aid in conjunction with alum. In case of untreated sample after sedimentation required alum dozing was $6 \mathrm{~mL} / 40 \mathrm{~mL}$ sample. After algal treatment, required alum dozing reduced to $4 \mathrm{~mL} / 40 \mathrm{~mL}$ sample. By adding $3 \mathrm{~mL} / 40 \mathrm{~mL}$ liquid natural coagulant as coagulant aid, alum dozing was further minimized to $1 \mathrm{~mL} / 40 \mathrm{~mL}$ sample. The odour was more tolerable than raw mixer after algal treatment but after adding alum aided by natural coagulant, the odour was more acceptable than before. The diversified technique can hopefully reduce a reliable chemical cost in treatment process, considerable amount of pollution load \& increase DO level and thus make effluent environment friendly to discharge. Finally, the DO level increases up to $6.56 \mathrm{mg} / \mathrm{L}$ at 33.7 ${ }^{\circ} \mathrm{C}$ and turbidity reduces to $183 \mathrm{NTU}$, $\mathrm{PH}$ reduces to 7.6, odour turns to be tolerable limit.
\end{abstract}

Keywords: Pollution load, algae, sedimentation, turbidity, DO, environment, coagulant.

\section{Introduction}

Tannery in Bangladesh seems a source of pollution load and waste water to all because there are 270 registered tanneries where approximately 220 MT raw hides and skins are taking for the production of leather in Bangladesh (Environmental Concerns, 2011). The leather industry has crossed the record \$1-billion mark in exports in 2013-2014 (Suman, 2015). According to the Department of Environment, the tanneries discharge 22,000 cubic meters of untreated liquid toxic waste daily (Human Rights Watch, 2012). Tanning is one of the oldest leather manufacturing process which is highly complex and characterized by high suspended solids, settle able solids, sulphide, chloride and chromium etc.

*Corresponding author's ORCID ID: 0000-0001-9882-2157 DOI: https://doi.org/10.14741/ijcet/v.8.4.14
When untreated tannery effluents discharged directly into the water bodies or into the open lands cause irreversible damage to the environment. As a result, Tanning Industry which is considered as highly polluted industry (Lanteigne, 2010). Tanneries generate wastewater in the range of $30-35 \mathrm{~L} / \mathrm{kg}$ skin or hide processed with variable $\mathrm{pH}$ and high concentrations of suspended solids. Major problems are due to waste water containing heavy metals, toxic chemicals, chloride, lime with high dissolved and suspended salts and other pollutants (Manivasagan, et $a l, 2011)$. Due to the inherent characteristics of tannery effluents, various physio-chemical techniques have been studied for the applicability to the treatment of tannery wastewater. Among these are coagulation, flocculation, ozonation, reverse osmosis, ion exchange and adsorption (Aboulhassan, et al, 2008).

Bio-sorption of heavy metals by algal biomass is an advantageous alternative, an appropriate and 
economically feasible method used for waste water and waste clean-up, because it uses algal biomass sometimes considered waste from some biotechnological processes or simply its high availability in coastal areas make it suitable for developing new by-products for waste water treatment plants (Brinza, et al, 2007). The use of dead cells offers several advantages: metal removal system is not subjected to metal toxicity, there is no requirement for growth media and nutrients, and adsorbed heavy metals can easily be desorbed and the biomass can be reused (Wike, et al, 2006). Algae have proved to possess high metal binding capacities due to the presence of polysaccharides, proteins or lipid on the surface of their cell walls containing some functional groups such as amino, hydroxyl, carboxyl and sulphate, which can act as binding sites for metals (Gupta, et al, 2008).

Coagulation indicates the process which colloidal particles and very fine solid suspensions are destabilized, so that they can begin to agglomerate if the conditions are appropriate. Flocculation refers to the process by which destabilized particles actually conglomerate into larger aggregates so that they can be separated from the waste water (Farajnezhad, et al, 2012). Coagulant chemicals with opposite charges of suspended solids are added to the water to neutralize the negative charges on non-settable solids (such as clay and color-producing organic substances). Once the charge is neutralized, the small suspended particles are capable of sticking together. These slightly larger particles are called micro flocs, and are not visible to the naked eye (Prakash, et al, 2014). Aluminum sulfate (alum), ferrous sulfate, ferric chloride and ferric chloro-sulfate are commonly used as chemical coagulants (Farajnezhad, et al, 2012).

While the effectiveness of these chemicals as coagulants is well-recognized, there are many disadvantages associated with usage of these coagulants such as ineffectiveness in low-temperature water, relatively high procurement costs, detrimental effects on human health, production of large sludge volumes and the fact that they significantly affect $\mathrm{pH}$ of treated water. There is also strong evidence linking aluminum-based coagulants to the development of Alzheimer's disease in human beings (Kazil, et al, 2013). Therefore, it is desirable to reduce the amount of chemical coagulant for wastewater treatment. In this paper this is done by combining coagulation with biosorption.

Coagulant aids are used to water during coagulation to improve agglomeration, build a stronger, more settle able floc, reduce the amount of coagulant and reduce the amount of sludge production. Here, the amount of chemical coagulant is further abated by using indigenous snail shell powder as a natural coagulant.

\section{Methodology}

\subsection{Sample collection}

Samples were collected from a renowned tannery nearby KUET campus. Collected samples were from different sections of beamhouse operations i.e. soaking, liming, deliming \& bating, pickling \& chrome tanning.

\subsection{Beamhouse operations}

Beamhouse operations are the initial stage of leather processing in tannery. The steps in the production of leather between curing to tanning are collectively referred as beamhouse operations. The consecutive processes namely pre-soaking, soaking, liming, deliming, bating, pickling and tanning are considered as beamhouse operation. The beamhouse operation has great importance for leather production. The flow chart for beamhouse operations from wet salted hide or skin is shown in below (Hashem, et al. 2014).

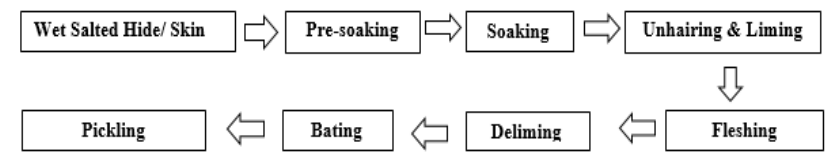

Fig. 1 Flow chart of beam house operations

\subsection{Settling of suspended and insoluble materials}

Settling operation was the preliminary operation of this work. In this stage, samples were mixed in a beaker with a definite ratio 2:1:1:1 of different waste liquors i.e. soaking, liming, deliming \& bating and pickle \& chrome liquor. They were agitated properly to mix up well and kept up to 5-6 hours' maximum for significant settle down. A continuous study represents that approximately $700 \mathrm{~mL}$ supernatant liquid was collected from the $1000 \mathrm{~mL}$ beaker where $300 \mathrm{~mL}$ was liquid \& suspended mixture (Sludge). By considering the settled sample as raw, different environmental parameters of the raw sample were measured.

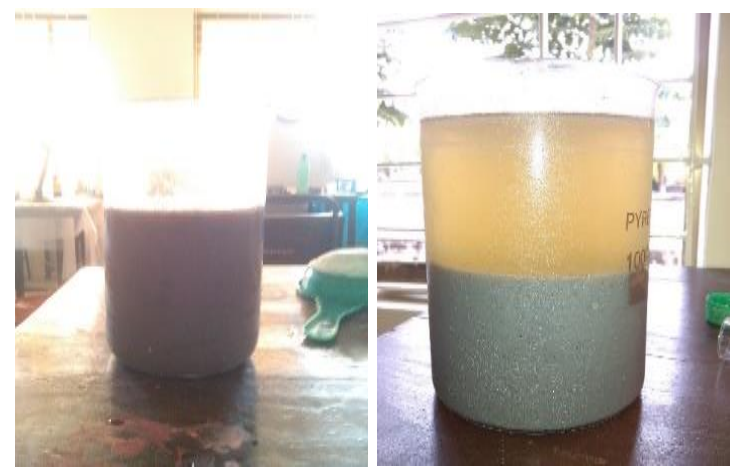

Fig. 2 Before settling Fig. 3 After settling 


\subsection{Materials}

The materials used for the desired treatment process are micro algae of Chlorophyte group, alum as coagulant and snail shell powder as coagulant aid. These algae are highly available in the rural area, urban area, ponds, lakes, rivers etc. The green algae are a large, informal grouping of algae consisting of the Chlorophyte and Cryophyte algae. The algae were collected from a lake of KUET campus. The algae were washed well thoroughly by continuous water flow. They were dried for two days in an oven at $50-60{ }^{\circ} \mathrm{C}$ for conditioning to protect from fungal attack and putrefaction. After conditioning they were grinded carefully and isolated micro particles by sieving. Reagent grade alum was used in the treatment process. Alum is grinded well and prepared a solution of alum in the concentration of $10 \mathrm{~g} / \mathrm{L}$. Snail shell was collected from rural area. It was washed well with continuous water flow and dried well. Then it was grinded well and prepared snail shell power solution in the concentration of $10 \mathrm{~g} / \mathrm{L}$. In this way, materials were prepared for the treatment process.

\subsection{Algal dosing}

Algal dosing is the process of choosing optimum amount of required algae for best performance on the basis of $\mathrm{pH}$, contact time, amount etc. Optimum dose of algae was selected on the basis of suspended solids adsorption percentage by different amount of algae at different $\mathrm{pH}$ and time. To do so firstly, 6 beakers each of $50 \mathrm{~mL}$ volume were taken and each of all the beakers was poured to $40 \mathrm{~mL}$ of raw sample. Then 0.1 g, $0.2 \mathrm{~g}, 0.3 \mathrm{~g}, 0.4 \mathrm{~g}, 0.5 \mathrm{~g}$ algae were taken in different beakers and kept them for $2.5 \mathrm{hrs}$. After that percentage of suspended solids adsorption by different amount of algae was calculated and was selected the best one. Secondly, 4 beakers each of $50 \mathrm{ml}$ size was filled by $40 \mathrm{~mL}$ of raw sample each was taken and was maintained different $\mathrm{pH}$ like 5.0, 6.0, 7.0 and 8.0 by using desired quantity of $0.1 \mathrm{~N}$ hydrochloric acid. After that all the samples were treated with the above selected optimum amount of algae for 2.5 hours and percentage of suspended solids adsorption at different $\mathrm{pH}$ was calculated and was selected the best one. The selected dose of algae is $0.3 \mathrm{~g} / 40 \mathrm{~mL}$ i.e. $7.5 \mathrm{~g}$ per one liter of raw sample at $\mathrm{pH} 6.0$ and time duration is 2.5 hours.

\subsection{Algal treatment process}

The algal treatment process starts with the application of definite amount of algae in the supernatant liquid (waste water) obtained from settling operation. The treatment process was run into normal condition. In this process, the required essentials are:

- Algae

- Beaker $(50 \mathrm{~mL})$
- Analytical balance

- Filter (Locally available)

- pH meter

- Oven

- Measuring Cylinder (10 mL \& $50 \mathrm{~mL})$

- Stirrer

At the beginning of treatment process, $40 \mathrm{~mL}$ of waste water was taken with measuring cylinder $(50 \mathrm{~mL}$ capacity) and poured into a beaker ( $50 \mathrm{~mL}$ capacity). Then adding hydrochloric acid to maintain solution $\mathrm{pH}$ 6.0. The optimum dose of algae selected for $40 \mathrm{ml}$ waste water processing was $0.3 \mathrm{~g}$. That amount of algae was measured with the help of analytical balance. Then measured amount of algae was poured into the waste water and mixed with the help of stirrer. The mixture was kept for two and half hours for the treatment process. After treatment, turbidity, DO level, $\mathrm{pH}$ were measured. A pretty good result was obtained.

\subsection{Coagulant dosing for raw sample}

After settling operation, raw sample of 6.0 was treated with different amount of alum as chemical coagulant to select dosing. From raw sample, $40 \mathrm{~mL}$ of raw sample was taken for each beaker. Alum solution was added to each beaker in sequential manner $3 \mathrm{~mL}, 4 \mathrm{~mL}, 5 \mathrm{~mL}, 6$ $\mathrm{mL}$ and $7 \mathrm{~mL}$ and vigorously stirred for five minutes. Then stirred the sample slowly for 10 minutes. After stirring, had rest for thirty minutes and checked out whether settling starts or not. Then $10 \mathrm{~mL}$ of upper solution was taken for suspended solids measurement.

\subsection{Coagulant dosing for algal treated sample}

At first five beakers about $50 \mathrm{~mL}$ were taken. Then the beakers were conditioned in oven and measured the weight of each beaker after drying. About $40 \mathrm{~mL}$ algal treated sample was taken in each beaker. Then alum dozing was made in the treated sample in each beaker. Then $1 \mathrm{~mL}, 2 \mathrm{~mL}, 3 \mathrm{~mL}, 4 \mathrm{~mL}, 5 \mathrm{~mL}$ solution of alum were added sequentially in the five beakers and vigorously stirred the sample for five minutes. Then the sample was stirred slowly for 10 minutes. After stirring, had rest for thirty minutes and checked out whether settling starts or not. Then $10 \mathrm{~mL}$ of upper solution was taken for the measurement of suspended solids.

\subsection{Optimization of chemical coagulant by using snail shell powder as natural coagulant}

The amount of alum for the processing of algal treated waste water can be partially reduced by adding snail shell powder as coagulant aid. Three beakers were taken and conditioned properly. In first beaker, $40 \mathrm{~mL}$ treated sample was taken and add Alum with snail shell powder with the ratio of 50:50 (Alum: snail shell powder). In second beaker, Alum with snail shell powder solution was added in $40 \mathrm{ml}$ sample with the ratio of 45:55 (Alum: snail shell powder). In third 
beaker, Alum with snail shell powder solution was added in $40 \mathrm{ml}$ sample with the ratio of 33:67 (Alum: snail shell powder). Then $10 \mathrm{~mL}$ of upper solution was taken for the measurement of suspended solids. The amount of alum was reduced in tannery waste water treatment by using snail shell powder as coagulant aid in conjunction with alum (Bina, et al, 2009).

\section{Results and discussion}

The amount of suspended solids was $47550 \mathrm{mg} / \mathrm{L}$ without algal treatment. The following tables represent the optimization of algal dosing for $40 \mathrm{~mL}$ solution.
From table 1,2 it is noticed that the percentage absorbance of suspended solids by algae is fluctuated. There may be different reasons: algal bleeding, optimum condition, $\mathrm{pH}$ range, time and so on and the selected dose of algae is $0.3 \mathrm{~g} / 40 \mathrm{~mL}$ of raw sample at pH 6 and time duration was two and half hours

The total amounts of suspended solids for different dozing of alum are given in table 3

The total amounts of suspended solids for different dozing of alum after algal treatment are given in table 4.

Table 1. Effect of amount of algae

\begin{tabular}{|c|c|c|c|c|}
\hline No of Beaker & $\begin{array}{c}\text { Amount of } \\
\text { Algae(g) }\end{array}$ & $\begin{array}{c}\text { Absorbed } \\
\text { (mg/L) }\end{array}$ & $\begin{array}{c}\text { Percentage of } \\
\text { absorbance (\%) }\end{array}$ & Remarks \\
\hline 1 & 0.1 & 20680 & 43.49 & \\
\hline 2 & 0.2 & 11070 & 23.28 & Accepted \\
\hline 3 & 0.3 & 28450 & 60.00 & \\
\hline 4 & 0.4 & 8580 & 18.00 & \\
\hline 5 & 0.5 & 23360 & 49.13 & \\
\hline
\end{tabular}

Table 2. Effect of $\mathrm{pH}$ on algae

\begin{tabular}{|c|c|c|c|c|c|}
\hline No of Beaker & $\mathrm{pH}$ & $\begin{array}{l}\text { Absorbed } \\
(\mathrm{mg} / \mathrm{L})\end{array}$ & $\begin{array}{c}\text { Percentage of } \\
\text { absorbance (\%) }\end{array}$ & $\begin{array}{c}\text { Amount of algae } \\
(\mathrm{g})\end{array}$ & Remarks \\
\hline 1 & 5.0 & 23890 & 50.00 & 0.3 & \\
\hline 2 & 6.0 & 30250 & 63.00 & 0.3 & Accepted \\
\hline 3 & 7.0 & 20640 & 43.00 & 0.3 & \\
\hline 4 & 8.0 & 24550 & 51.63 & 0.3 & \\
\hline 5 & Raw & 25100 & 52.78 & 0.3 & \\
\hline
\end{tabular}

Table 3. Coagulant dosing for raw sample

\begin{tabular}{|c|c|c|c|}
\hline No of Beaker & $\begin{array}{c}\text { Amount of Alum }(\mathrm{mL}) / 40 \mathrm{~mL} \text { [Solution } \\
\text { Concentration } 10 \mathrm{~g} / \mathrm{L}]\end{array}$ & $\begin{array}{c}\text { Amount of Suspended Solids } \\
\text { (mg/L) }\end{array}$ & Remarks \\
\hline 1 & $3 \mathrm{~mL}$ & 29046 & \\
\hline 2 & $4 \mathrm{~mL}$ & 28356 & \\
\hline 3 & $5 \mathrm{~mL}$ & 26750 & Accepted \\
\hline 4 & $6 \mathrm{~mL}$ & 24900 & \\
\hline 5
\end{tabular}

Table 4. Coagulant dosing after Algal Treatment

\begin{tabular}{|c|c|c|c|}
\hline No of Beaker & $\begin{array}{c}\text { Amount of Alum (mL)/40 mL } \\
\text { [Solution Concentration } 10 \mathrm{~g} / \mathrm{L}]\end{array}$ & $\begin{array}{c}\text { Amount of Suspended } \\
\text { Solids (mg/L) }\end{array}$ & Remarks \\
\hline 1 & $1 \mathrm{~mL}$ & 14370 & \\
\hline 2 & $2 \mathrm{~mL}$ & 12890 & Accepted \\
\hline 3 & $3 \mathrm{~mL}$ & 9920 & \\
\hline 4 & $4 \mathrm{~mL}$ & 9610 & \\
\hline 5 & $5 \mathrm{~mL}$ & & \\
\hline
\end{tabular}


Table 5 Optimization of chemical coagulant by using snail shell powder as natural coagulant

\begin{tabular}{|c|c|c|c|c|}
\hline $\begin{array}{c}\text { No of } \\
\text { beaker }\end{array}$ & $\begin{array}{c}\text { Amount of Alum with snail shell } \\
\text { powder }(\mathrm{mL}) / 40 \mathrm{~mL} \text { [Solution } \\
\text { Concentration } 10 \mathrm{~g} / \mathrm{L}]\end{array}$ & $\begin{array}{c}\text { Alum: Snail Shell } \\
\text { Powder Solution }\end{array}$ & $\begin{array}{c}\text { Amount of Suspended } \\
\text { Solid (mg/L) }\end{array}$ & Remarks \\
\hline 1 & $2.0 \mathrm{~mL}+2.0 \mathrm{~mL}$ & $50: 50$ & 8425 & \\
\hline 2 & $1.4 \mathrm{~mL}+2.6 \mathrm{~mL}$ & $44: 56$ & 8100 & Accepted \\
\hline 3 & $1 \mathrm{~mL}+3 \mathrm{~mL}$ & $33: 67$ & 7820 & . \\
\hline
\end{tabular}

Table 6 Environmental parameters (raw sample) and devices

\begin{tabular}{|c|c|c|c|c|c|}
\hline Parameter & DO & Turbidity & $\mathrm{pH}$ & Salinity & Conductivity \\
\hline Raw Sample & $\begin{array}{c}0.25 \mathrm{mg} / \mathrm{L} \text { at } \\
33.7{ }^{\circ} \mathrm{C}\end{array}$ & $873 \mathrm{NTU}$ & 9.1 & $\begin{array}{c}24.4 \mathrm{ppt} \text { at } 33.7 \\
{ }^{\circ} \mathrm{C}\end{array}$ & $\begin{array}{c}45.00 \mathrm{mS} / \mathrm{m} \text { at } \\
33.6{ }^{\circ} \mathrm{C}\end{array}$ \\
\hline Device & $\begin{array}{c}\mathrm{HQ} 40 \mathrm{~d} \text { of } \\
\mathrm{HACH}\end{array}$ & $\begin{array}{c}2100 \mathrm{P} \text { Turbid Meter } \\
\text { of HACH }\end{array}$ & $\begin{array}{c}\text { EZDO } \\
\text { PH5011 }\end{array}$ & BOECO CT-676 & BOECO CT-676 \\
\hline
\end{tabular}

Table 7 Environmental parameters (treated sample) and devices

\begin{tabular}{|c|c|c|c|c|c|}
\hline Parameter & DO & Turbidity & pH & Salinity & Conductivity \\
\hline Treated Sample & $\begin{array}{c}6.56 \mathrm{mg} / \mathrm{L} \\
\text { at } 33.6^{\circ} \mathrm{C}\end{array}$ & $183 \mathrm{NTU}$ & 7.6 & $\begin{array}{c}18.1 \mathrm{ppt} \text { at } \\
33.7^{\circ} \mathrm{C}\end{array}$ & $33.46 \mathrm{mS} / \mathrm{m}$ at $33.6^{\circ} \mathrm{C}$ \\
\hline Device & $\begin{array}{c}\mathrm{HQ} 40 \mathrm{~d} \text { of } \\
\mathrm{HACH}\end{array}$ & $\begin{array}{c}2100 \mathrm{P} \text { Turbid Meter } \\
\text { of HACH }\end{array}$ & $\begin{array}{c}\text { EZDO } \\
\text { PH5011 }\end{array}$ & $\begin{array}{c}\text { BOECO CT- } \\
676\end{array}$ & BOECO CT-676 \\
\hline
\end{tabular}

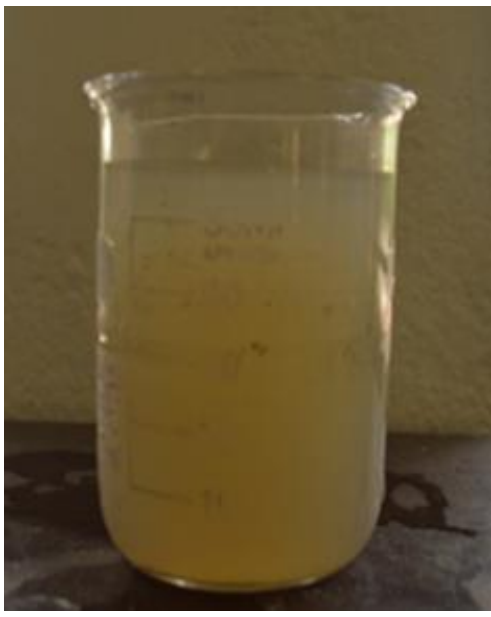

Fig. 4 Before Treatment

From table 3, 4, 5 it is noticed that the amount of suspended solids reduced in a sequential manner. Finally, the amount of suspended solids was reduced to $7820 \mathrm{mg} / \mathrm{L}$ from $47550 \mathrm{mg} / \mathrm{L}$.

Different environmental parameters are measured of raw sample by the utilization of different devices. Some environmental parameters of raw sample and the devices used for the measurement are given in the table 6.

After combined treatment i.e. algal treatment and chemical coagulation aided by natural coagulant some environmental parameters of treated sample were measured by the utilization of different devices. Some environmental parameters of treated sample and used devices for measurement are given in table 7 .

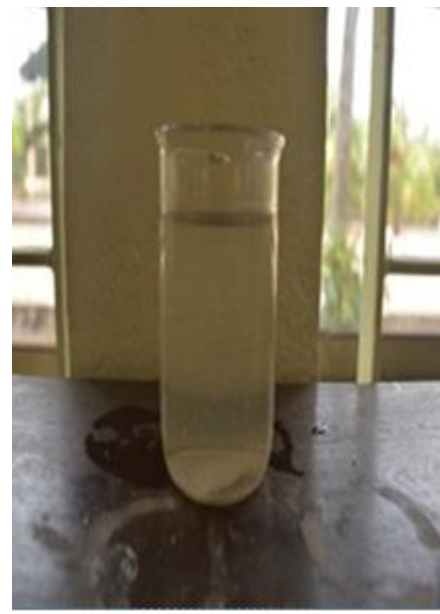

Fig. 5 After Treatment

By comparing table $6 \& 7$, it is observed that a pretty good result was obtained. The DO level of treated sample is increased $6.56 \mathrm{mg} / \mathrm{L}$ at $20{ }^{\circ} \mathrm{C}$ from 0.25 $\mathrm{mg} / \mathrm{L}$ at $20{ }^{\circ} \mathrm{C}$ of raw sample (waste liquor). Another two parameters are also reduced to a significant amount; i.e. the former turbidity was 873 NTU and after treatment it is reduced to 183 NTU. The $\mathrm{pH}$ is measured i.e. 7.6 which is in a safe level. The discharge limit of water to environment is $6-9 \mathrm{pH}$.

The total amounts of suspended solids through optimization of chemical coagulant by using natural coagulant are given in fig. 4 and 5.

\section{Conclusions}

Dead algal biomass is a useful alternative to conventional adsorption products for heavy metal 
uptake from tannery effluents. Here the following points are concluded from this work:

1) Development of bio-sorption processes with algal biomass requires further investigation, like Selectivity of algal species, Regeneration and reusability of algal biomass, Simulation and modelling of processes etc.

2) After the usage of green algae as bio-sorbents with chemical coagulation process aided by indigenous coagulant shows good efficiency of reducing pollution load from tannery waste water.

3) During the research work, we used $0.3 \mathrm{~g}$ algae at pH 6.0 within 2.5 hours' duration for treating 40 $\mathrm{mL}$ sample. After treatment of sample with algae, amount of waste particles reduced from 47550 $\mathrm{mg} / \mathrm{L}$ to $28880 \mathrm{mg} / \mathrm{L}$. That means $60.73 \%$ absorbance obtained by using such amount of algae. Therefore, it can be concluded that green algae can be used as bio-sorbents in treatment process.

4) Snail shell powder can be used as coagulating aid in waste water treatment process. Here $4 \mathrm{~mL}$ alum solution used as optimum doze. By using such amount in algal treated sample, the amount of total waste particles reduced to $9920 \mathrm{mg} / \mathrm{L}$. After the infusion of coagulation aid the amount of waste particles reduced to $7820 \mathrm{mg} / \mathrm{L}$. Thus, the alum dosing can be reduced for waste water treatment.

5) The use of this approach can confer solutions for the reduction of pollution load from waste water of tannery without being exposed to potential health hazard.

\section{Acknowledgements}

The authors would like to express appreciation to Department of Leather Engineering, Khulna University of Engineering \& Technology for supporting the research work. The authors would also like to gratefully thankful for the support and assistance provided by Mr. Md. Anis, Mr. Md. Hafizul Islam and Mr. Hanif of Environmental Engineering Laboratory, Leather Engineering Department, Khulna University of Engineering \&Technology.

\section{References}

Environmental Concerns: Hazaribagh Tannery area and Present Relocation Scenario, (2011).

Suman Saha, (2015). Leather Industry Hits Record Exports: $\$ 1 b$, The Daily Star.

Human Rights Watch, (2012), Toxic Tanneries: The Health Repercussions of Bangladesh's Hazaribagh Leather.

D. Lanteigne, Colours of Water: Bangladesh Leather Tanneries, Our World, (2010).

D. G, R. Manivasagan, and R. Natarajan, (2011), Kinetic Studies on Biodegradation of Tannery Wastewater in a Sequential Batch Bioreactor", Journal of Biotech Research, vol. 3, pp. 19-26.

M. A. Aboulhassan, S. Souabi, and A. Yaacoubi, (2008), Pollution Reduction and Biodegradability Index Improvement of Tannery Effluents", International Journal Environment Science and Technology, vol. 5 (1), pp. 11-16.

L. Brinza, M. J. Dring, and M. Gavrilescul, (2007), Marine Micro and Macro Algal Species as Bio-sorbents for Heavy Metals", Environmental Engineering and Management Journal, vol. 6 (3), pp. 237-251.

A. Wike, R. Buchholz, and G. Bunke, (2006), Selective Biosorption of Heavy Metals by Algae", Environmental Biotechnology, vol. 2 (2), pp. 47-56.

V. K. Gupta, and A. Rastogi, (2008), Bio-sorption of Lead from Aqueous Solutions by Green Algae Spirogyra Species: Kinetics and Equilibrium Studies", Journal of Hazardous Materials, vol. 152, pp. 407-414.

H. Farajnezhad, and P. Gharbani, (2012), Coagulation Treatment of Wastewater in Petroleum Industry Using Poly Aluminium Chloride and Ferric Chloride", International Journal of Recent Research and Applied Studies, vol. 13 (1), pp. 306-310.

N. B. Prakash, V. Sockan, and P. Jayakaran, (2014), Waste Water Treatment by Coagulation and Flocculation", International Journal of Engineering Science and Innovative Technology, vol. 3 (2), pp. 479-484.

T. Kazi1, and A. Virupakshi, (2013), Treatment of Tannery Wastewater Using Natural Coagulants", International Journal of Innovative Research in Science Engineering and Technology, vol. 2 (8), pp. 4061-4068.

M. A. Hashem, A. Islam, S. Paul, and S. Nasrin, (2014), Generation of Ammonia in Deliming Operation from Tannery and Its Environmental Effect: Bangladesh Perspective", International Journal of Renewable Energy and Environmental Engineering, vol.2 (4), pp. 266-270.

B. Bina, M. H. Mehdinejad, M. Nikaeen, and H. M. Attar, (2009), Effectiveness of Chitosan as Natural Coagulant Aid in Treating Turbid Waters", Iranian Journal of Environmental Health Science \& Engineering, vol. 6 (4), pp. 247-252. 